\title{
Kálmosgyökértörzs-teák B-azaron-tartalmának meghatározása és fogyasztásának felmérése napjainkban
}

\section{Bencsik Tímea*, Kovács Kinga}

PTE GYTK Farmakognóziai Intézet, 7624 Pécs, Rókus u. 2.

*e-mail: timea.bencsik@aok.pte.hu

A gyógyteák napjainkban növekvő népszerűségnek örvendenek. Még a klinikailag kevésbé vizsgált teáknak is jelentős szerepe lehet a gyógyászatban, hiszen egyes indikációkban hiánypótló szerepet tölthetnek be. A lehetőségek mellett azonban fontos felhívni a betegek figyelmét a gyógyteák fogyasztásával kapcsolatos veszélyekre is.

Gyógyszertárban dolgozó szakemberek kerestek meg bennünket egy esettel, amelynek során egy betegnél kálmosgyökértörzs-tea fogyasztását követően kellemetlen mellékhatás (szokatlanul erős menstruációs vérzés) jelentkezett. Ezért készítettünk egy kérdőívet, amellyel célunk volt felmérni, hogy kálmosgyökértörzsből készített tea fogyasztása során tapasztalt-e bárki más is hasonló vagy egyéb mellékhatásokat. Emellett négy különböző gyártótól (Herbária, Adamo, Naturland, JuvaPharma) származó kálmosgyökértörzs monoteát is vizsgáltunk: tartalmaznak-e 6-azaront, és ha igen, abból mennyi oldódik ki, ha vizes kivonatot (vagyis a csomagoláson feltüntetett javaslat szerint teát) készítünk.

A kérdőíves felmérésből kiderült, hogy Pécs és Szombathely környékén meglehetősen kevesen ismerik és alkalmazzák ezt a gyógynövényt. Az interjú kapcsán a kálmosnak tulajdonított mellékhatást sem a szakirodalmi adatok között, sem a kérdőíves felmérés során nem említette egy beteg sem, illetve a megkérdezett pécsi és szombathelyi fogyasztók semmilyen más panaszt nem tapasztaltak, sőt, nagy többségük tünetei (étvágytalanság, rossz emésztés, puffadás) megszűntek a gyógynövény fogyasztását követően.

A HPLC-mérések alapján a kálmosgyökértörzs monoteák mindegyike tartalmazott 6 -azaront, és mindegyik termék esetén elmondható, hogy ha a beteg a csomagoláson feltúntetett módon készíti el a teát, és mind a $200 \mathrm{ml}-\mathrm{t}$ el is fogyasztja, a 6 -azaron rossz vízoldékonysága ellenére még így is messzemenően (2-12-szeresen) túllépi a hatóságok által javasolt maximális $115 \mu$ g-os napi 6 -azaron-bevitelt.

Köszönetnyilvánítás: Köszönjük gyógyszertárban dolgozó kollégáink témafelvetését és az adatközlők hozzájárulását a kérdőíves felméréshez. Az analitikai mérések kivitelezéséhez anyagi támogatást a PTE ÁOK Posztdoktori Ösztöndíj program biztosított. 